\title{
EXPERT VIEWS ON THE EVOLUTION - CREATION CONTROVERSY. A SURVEY REPORT
}

\begin{abstract}
This paper presents sample results from a poll conducted among experts (scientists, philosophers and theologians) regarding the roots of the controversy between the evolutionary account of human origin and religious convictions about creation. It appears that the position one takes in this controversy is influenced much more by one's opinions than professional background. The controversy is usually only seemingly 'solved' at the level of a priori assumptions, erroneous definitions of 'evolutionism' and 'creationism', semantic viewpoints, epistemological positions and pragmatic choices. The core issues in the controversy (e.g., the role and meaning of chance in random evolutionary factors versus divine providence, or problems stemming from a body-soul dualistic anthropology) are widely neglected and do not play a significant role in deciding one's views on the matter.
\end{abstract}

Keywords: origin of man; beliefs; survey research; creationism; evolutionism

1. Introduction and background. 2. Basic data. 3. Biological versus theological accounts of the origin of man. 3.1. Specialization, beliefs and the possibility of reconciliation. 3.2. Reasons for denying the possibility of reconciliation. 4 . Conclusions.

\section{INTRODUCTION AND BACKGROUND}

When Charles Darwin published On the Origin of Species (1859) his work raised many objections, first of all among scientists. Darwin questioned the long-lived view that species do not change, which had allowed Linnaeus to classify all the known species in his famous Systema Naturae - one of the cornerstones of biology in Darwinian times. Apart from this general abuse of biological dogmas, there were several specific problems which many scientists of the time pointed to in order to show, if not the general fallacy of Darwin's theory, at least its serious flaws. What are the reasons of the changeability of 
a species? How can natural selection preserve substantial changes as required by the new theory, if changes observed (and also deliberately brought about) in farming were of a restricted span? Why are new characteristics not 'washed-out' in subsequent generations? If changes are small and accumulate over long periods of time, why are there no fossil traces of intermediate forms? If the Earth is about 100 million years old - as it had been convincingly (though wrongly, as it turned out later) demonstrated by Lord Kelvin - how can Darwin date some of his findings at 300 million years? These are but a few of the important scientific questions that Darwin could not satisfactorily address. He also abused the scientific methodology generally accepted in his times. Two hundred years before, Francis Bacon had declared induction as the proper method for scientific inquiry. Darwin offered "wild hypothesizing" instead - but scientists wanted proof.

Naturally, most - if not all - of such problems have been solved over the course of time. New fossil findings, serious re-dating of the age of the Earth, and, above all, the development of genetics have gradually made Darwinian views the basis for nearly all biological disciplines and proved evolutionary explanations plausible and successful.

Other controversies that the theory of evolution brought about concerned the fact that it allegedly undermined religious beliefs in creation. Such controversies appear to have undergone a similar course as those over the scientific virtues of Darwin's theory: from strong opposition to finding ways of reconciling the new scientific findings with religious and theological views. At first, many feared the new theory as a result of ideological interpretations, such as Ernst Haeckel's, maintaining that the theory of evolution would finally destroy Christianity and the Church. ${ }^{1}$ This concern is exemplary voiced in the following remark by the wife of an Anglican bishop: "Descendent from the apes! My dear, let us hope it is not so; but if it

1 E. Haeckel, Ueber unsere gegenwärtige Kenntnis vom Ursprung des Menschen, Verlang von E. Strauss, Bonn 1899. 
is, that it does not become generally known". ${ }^{2}$ There were also more serious and official reactions expressing the same worries as this rather humorous remark. The Episcopalian Church issued an edict that read: "If this hypothesis be true, then is the Bible an unbearable fiction". ${ }^{3}$ Preliminary reception of Darwin's work was quite hostile in the Catholic Church as well. Many theologians would agree with John Pohle who, in his textbook on Dogmatics published in the first decade of the 20th century, declared that the description of creation in Genesis is realistic - it is a true story. Therefore, Darwin offends God who directly created the body of the first human. ${ }^{4}$

The opinion of even the most noble theologians perhaps would not matter, had they not been officially backed up by Church authorities. The Papal Biblical Council, in a decree issued in 1909, stressed that the most fundamental truths of faith include the convictions that God is the direct Creator of the first human, that woman originates from man's body, and that all humanity has its roots in a unique, single beginning. ${ }^{5}$ Although the document does not mention the theory of evolution, it seems to deny implicitly not only some important evolutionary views but, indeed, certain foundational biological theses.

Apart from such reactions, which were close to declaring war between Darwinian science and religion, there were also thinkers who, nearly from the very beginning pointed to ways of reconciliation. James McCosh, the President of the College of New Jersey (which later became Princeton University) suggested that the approach of 'either God or Darwin' is an altogether wrong opposition: "We give

2 P. Barret, Science and theology since Copernicus. The search for understanding, Bloomsbury - T. and T. Clark, London - New York 2004, 98.

3 Quoted in: C.A. Russell, Cross-currents: interactions between science and faith, London 1985, 149.

4 J. Pohle, Lehrbuch der Dogmatik, vol. 1, Schöningh, Padeborn 1908, 427.

5 "De charactere historico trium priorum capitum Geneseos. Sul carattere storico dei tre primi capitoli della Genesi”, Acta Apostolicae Sedis, vol. 1, Libreria Editrice Vaticana 1909, 567-569. 
to science the things that belong to science, and to God the things that are God's. When a scientific theory is brought before us, our first enquiry is not whether it is consistent with religion, but whether it is true". 6

Another prominent figure in the Anglican Church, Frederic Temple, later Archbishop of Canterbury, went even further and maintained that science and religion are not only independent, but that the two can collaborate for a better understanding of the world, created by God and governed by laws discovered by science: "[The Creator] impressed on certain particles of matter... such inherent powers that in the ordinary course of time living creatures such as the present were evolved". 7 The voices of reconciliation, pointing mainly to the independence of the biblical account of creation and the evolutionary explanation of the development of the living world. included Catholic theologians as well. Laurentio Janssens, for example, lamented in his Summa Theologica a certain disinterest of theology in scientific results. For him, one of the most important truths about humans in the Bible is that God created them. From a theological point of view, however, it is unimportant how the human body originated. 8

Similar views were also expressed by Bernhard Bartmann who, in his textbook on Dogmatics, made an explicit reference to the theory of evolution, or rather to those theologians who thought that in order to defend true faith one has to deny the Darwinian account. He suggested that God created the human soul out of nothing, and the body out of existing matter. Therefore, there is no need to reject the hypothesis of the evolutionary origin of man. ${ }^{9}$

6 Quoted in: P. Barret, Science and theology since Copernicus. The search for understanding, op. cit., 101.

7 Quoted in: J. Moore, The Post-Darwinian Controversies, Cambridge 1977, 220.

8 L. Janssens (ed.), Summa Theologica ad modum commentarii in Aquinatis summam praesentis aevi studiis aptatam, vol. 1, Herder, Freiburg 1912.

9 B. Bartmann, Lehrbuch der Dogmatik, vol. 1, Herder, Freiburg 1911. 
Although the reference to the body-soul dualism here seems to raise some problems, the opposition between the 'independence view' on evolutionary findings versus theological accounts of creation could not be clearer.

As we have seen, the first solutions to the problem of the alleged controversy between the biblical account of creation and the evolutionary understanding of the origin of man were suggested about a century ago. They either applied what was later labeled an 'independence view' or called for an integrating approach to creation end evolution - a line of thought that has been indeed pursued by many ever since. ${ }^{10}$ Given the long history of such attempts, it is all the more surprising that the controversy surfaces again and again. This is shown for instance by the discussion ensued following the publication of a short but influential paper by Christoph Schönborn, ${ }^{11}$ including his own reply to his adversaries, ${ }^{12}$ or the reception ${ }^{13}$ received by Richard Dawkins' The God Delusion. ${ }^{14}$ While the general public may not be aware of academic disputes and their results, and can thus be easily attracted by the simple 'either religion or science' view, the members of academia should know, if not the historical details of the evolution-creation controversy, then at least other, perhaps more sophisticated approaches to the problem. The question is, therefore, whether those solutions are ignored rather than implausible? In other words, is the controversy in question only a pseudo-problem raised by a lack of knowledge or ill-convinced arguments, such as those put forward lately by the proponents of the 'Intelligent Design' theory,

10 E.g. K. Kloskowski, Filozofia ewolucji i filozofia stwarzania, vol. 1: Między ewolucją a stwarzaniem, Wydawnictwo ATK, Warszawa 1999, 190-213.

11 C. Schönborn, "Finding Design in Nature", New York Times, 2005, July 7.

12 C. Schönborn, Chance or purpose? Creation, evolution, and a rational faith, ed. H.P. Weber, transl. H. Taylor, Ignatius Press, San Francisco 2007.

13 A.E. McGrath, J.C. McGrath, The Dawkins delusion. Atheist fundamentalism and the denial of the divine, InterVarsity Press, Downers Grove 2007.

14 R. Dawkins, The God Delusion, Houghton Mifflin, Boston 2006. 
or are there rational reasons for holding each of the conflict view? In the latter case, what are those reasons? These were the main questions investigated in the research project Current controversies about buman origins - Between anthropology and the Bible undertaken recently in Poland. ${ }^{15}$ The research methods employed included questionnaires, one of which was addressed to experts in the relevant disciplines, i.e. biological sciences, theology, and philosophy. This paper presents sample results from that questionnaire.

\section{BASIC DATA}

The questionnaire sent to experts ${ }^{16}$ comprised 12 questions and was distributed in a few hundred copies among specialists in biological sciences, theology, and philosophy. We received 112 completed questionnaires, which - given a very narrow and welldefined group of respondents - are sufficient for further analysis. By 'experts' ('specialists') we meant senior faculty members of the relevant disciplines. Representatives of biological sciences included specialists in human biology (anthropology) and genetics, but also environmental studies, agricultural sciences and medicine. Philosophers would belong to different traditions - from 'Christian' and classic philosophy to analytical philosophy. As for theologians, they should be expected - given that the poll took place in Poland,

15 The project was one of the winners in the Global Perspectives on Science and Spirituality programme (GPSS), phase 1, carried out by Elon University and Université Interdisciplinaire de Paris (No ID 100014).

16 In the research we also distributed a questionnaire among students of biology and environmental sciences, theology (both lay people and clergy) and philosophy. Sample results from this questionnaire have been published elsewhere (J. Tomczyk, G. Bugajak, Wokół ewolucji i kreacji - wstępna analiza ankiet nauczycieli i studentów, Studia Ecologiae et Bioethicae 4(2006), 181-199; J. Tomczyk, G. Bugajak, Kontrowersje wokół powstania człowieka - wstępna analiza ankiet studentów, Studia Ecologiae et Bioethicae 5(2007), 43-59; J. Tomczyk, G. Bugajak, On Evolution and Creation. Problem solved? - The Polish example, Zygon - Journal of Religion and Science 44(2009), 859-878). 
and the choice of theological faculties originally included - to be catholic scholars (the respondents were encouraged to state their denomination, but many of them chose not to do so).

We received 40 replies from experts in biological sciences, 26 replies from theologians and biblicists, 40 replies from philosophers and 6 replies from other experts, of which 4 in to natural sciences (like geology and chemistry) and 2 in pedagogy. We have grouped the responses as shown in Table 1.

Tab. 1. The number of respondents in relation to their field of expertise

\begin{tabular}{|l|c|c|c|}
\hline & $\begin{array}{c}\text { biological sciences and } \\
\text { other natural sciences }\end{array}$ & philosophy & $\begin{array}{c}\text { theology, biblical studies } \\
\text { and other humanities }\end{array}$ \\
\hline $\mathrm{n}$ & 44 & 40 & 28 \\
\hline$\%$ & 39.3 & 35.7 & 25 \\
\hline
\end{tabular}

The questionnaire also asked about the attitude of respondents toward religious faith. The answers were as follows: 66 practicing believers, 13 non-systematically practicing believers, 5 non-practicing believers, and 24 non-believers. Four respondents did not choose any of these options, but wrote side comments such as "I'm searching for truth" or "agnostic", which allows to count them among nonbelievers, at least in so far as they do not consider themselves as belonging to any institutional religious communities, especially Christian ones. Their reluctance to choose the 'non-believer' option can be explained by the close association in the Polish language of the word 'non-believer' with the word 'atheist' or even 'anti-theist'. We have grouped the responses to this question shown in Table 2. 
Tab. 2. Attitude toward religious faith

\begin{tabular}{|l|c|c|}
\hline & believers & non-believers \\
\hline $\mathrm{n}$ & 84 & 28 \\
\hline$\%$ & 75 & 25 \\
\hline
\end{tabular}

\section{BIOLOGICAL VERSUS THEOLOGICAL ACCOUNTS OF THE ORIGIN OF MAN}

One of the questions investigated concerned the possibility of attaining a coherent view of human origins, based on both the theory of evolution and the biblical account of creation. We asked respondents whether it is possible to reconcile the natural vision of human origins with theology.

The remaining part of this paper offers an analysis of the responses to this question.

\subsection{SPECIALIZATION, BELIEFS AND THE POSSIBILITY OF RECONCILIATION}

The majority of poll participants - 74 - think that the reconciliation in question is possible. 19 participants answered "no", 16 found it difficult to say, and 3 did not choose any of the suggested answers. The question had also an 'open section', which respondents to justify their views. The comments given in this section, together with the answers given to a related question: "Is there a conflict between evolutionism and creationism?", enable us to classify two of the "no answer' replies as positive ones and the remaining one as a negative answer. Final results are shown in Table 3. 
Tab. 3. Is it possible to reconcile the natural vision of human origins with theology?

\begin{tabular}{|l|c|c|c|}
\hline & yes & no & difficult to say \\
\hline $\mathrm{n}$ & 76 & 20 & 16 \\
\hline$\%$ & 67.9 & 17.8 & 14.3 \\
\hline
\end{tabular}

It might be expected that those working in natural sciences, especially biologists who were the majority among scientists represented in the poll (91\%), would be inclined to deny the possibility of attaining a coherent view on human origins based on both scientific findings concerning evolution and theological accounts of creation. It is not only the 'received view' that scientists are generally sceptical about religion. It is also clear in the results of other polls showing that, for example, over $70 \%$ of biologists in the USA hold quite negative opinions on religious beliefs ${ }^{17}$. Therefore, we expected that the scientists represented in our research should tend toward the negative answer to the question of reconciliation. Even more obvious should be an inclination of theologians to the positive answer. Theology, after a period of sharp disagreement with the evolutionary approach to the origins of man, appears to have accepted over the last century that scientific theories may inform theological thought. While our results support expectations with regard to theologians and biblicists, the opinion of scientists diverges from our initial expectations (see Figure 1).

17 E.H. Ecklund, C.P. Scheitle, Religion among Academic Scientists: Distinctions, Disciplines and Demographics, Social Problems 54(2007)2, 296. 
Is it possible to reconcile the natural vision of human origins with theological thought?

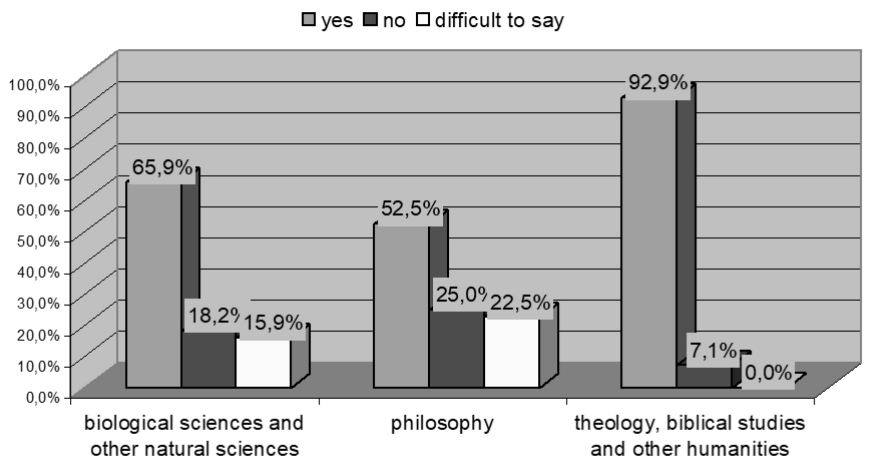

Fig. 1: Possibility of reconciliation of evolution and creation versus the field of specialisation

Although the relation between one's profession and the answer given to the question is statistically relevant (see Table 4), the level of support for reconciliation among scientists is surprisingly high. This may show a specificity of Polish scientists in comparison with their Western colleagues. But it may also indicate that there are reasons other than profession for holding 'complementary' or 'conflict' views on science and religion. Precisely the latter supposition finds strong support in the results of the questionnaire.

Tab. 4. Possibility of reconciliation of evolution and creation versus field of specialization

\begin{tabular}{|l|c|r|c|}
\hline & yes & no & difficult to say \\
\hline biological sciences and other natural sciences & 29 & 8 & 7 \\
\hline philosophy & 21 & 10 & 9 \\
\hline theology, biblical studies and other humanities & 26 & 2 & 0 \\
\hline
\end{tabular}
$\chi^{2}=12.91 ; \mathrm{df}=4 ; \mathrm{p}=0.012$

The comparison of the answer to our question and the attitude toward religious beliefs yields significant results. The vast majority 
of believers (over 77\%) maintain that a reconciliation between theology and science on the issue of human origins is possible, and only about $10 \%$ think otherwise. Believing professionals (bearing in mind that the respondents were specialists in their disciplines) therefore are far from holding a 'conflict' view on creation and evolution with respect to human origins. This is in contrast with non-believers, among whom the same number hold the 'coherence' and the 'conflict' view - see Figure 2.

Is it possible to reconcile the natural vision of human origins with theological thought?

$\square$ yes $\square$ no $\square$ difficult to say

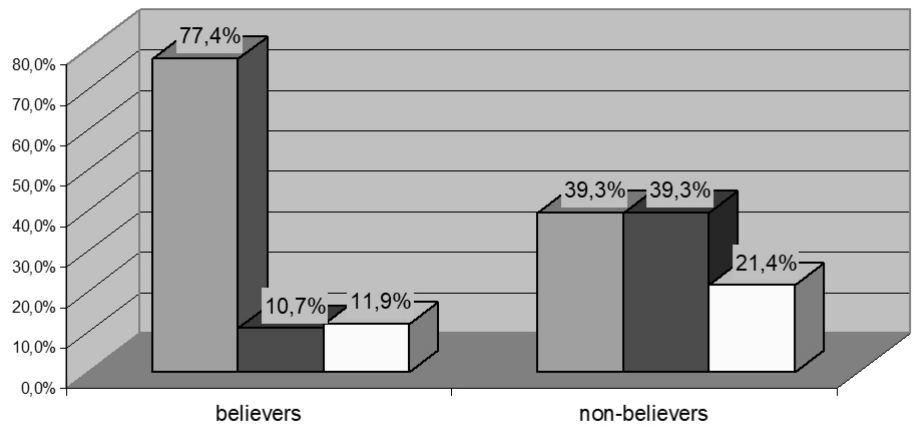

Fig. 2: Possibility of reconciliation of evolution and creation versus the attitude towards religious beliefs

These results show that believing professionals do not feel attracted to any 'special' ways of 'salvaging' their faith in the face of biological findings, which makes the situation in Poland different from countries where accounts such as the Intelligent Design theory, which denies evolutionary explanations of certain important features of the living world, seem quite popular and are put forward by professionals, biologists included, who apparently do so for religious reasons.

What is more important is that the relation between the answer to the question of reconciliation and the attitude toward religious beliefs is stronger (see Table 5) than the relation between our question and one's field of specialization (profession). 
Tab. 5. Possibility of reconciliation of evolution and creation versus attitude toward religious beliefs

\begin{tabular}{|l|c|c|c|}
\hline & yes & no & difficult to say \\
\hline believers & 65 & 9 & 10 \\
\hline non-believers & 11 & 11 & 6 \\
\hline
\end{tabular}

$\chi^{2}=15.42 ; \mathrm{df}=2 ; \mathrm{p} \leq 0.001$

The results show, therefore, that the one's position in the evolutioncreation controversy has more to do with one's opinion and beliefs rather than with one's profession. This contradicts a fairly popular opinion associating the rejection of religious belief in creation with professional background. One is more likely to deny the possibility of reconciliation between the evolutionary account of human origins and the biblical truth of creation on the grounds of one's (dis)belief, rather than of one's awareness of the virtues of the theory of evolution.

This conclusion is reinforced if we compare the distribution of negative answers to the question of reconciliation among representatives of different professions and among believers and nonbelievers (Figures 3 and 4).

Is it possible to reconcile the natural vision of human origins

with theological thought?

$\square$ representation in the poll $\square$ answer: No

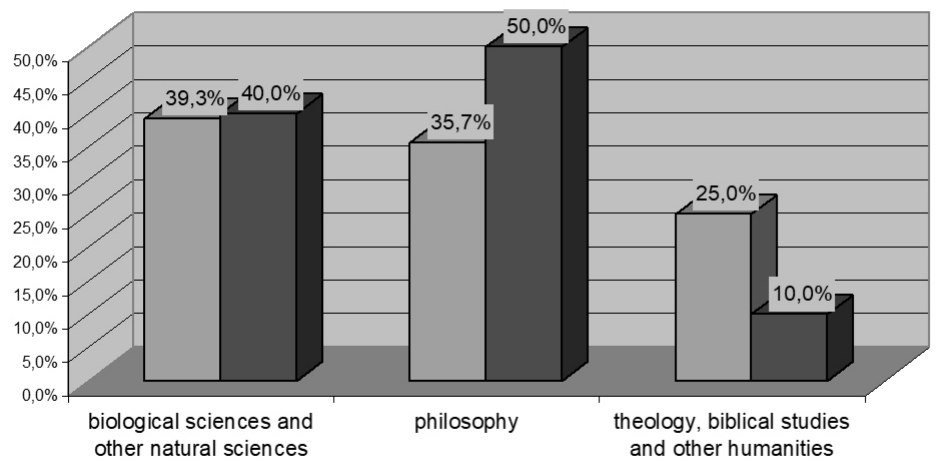

Fig.3: 'No' answer with regard to profession 


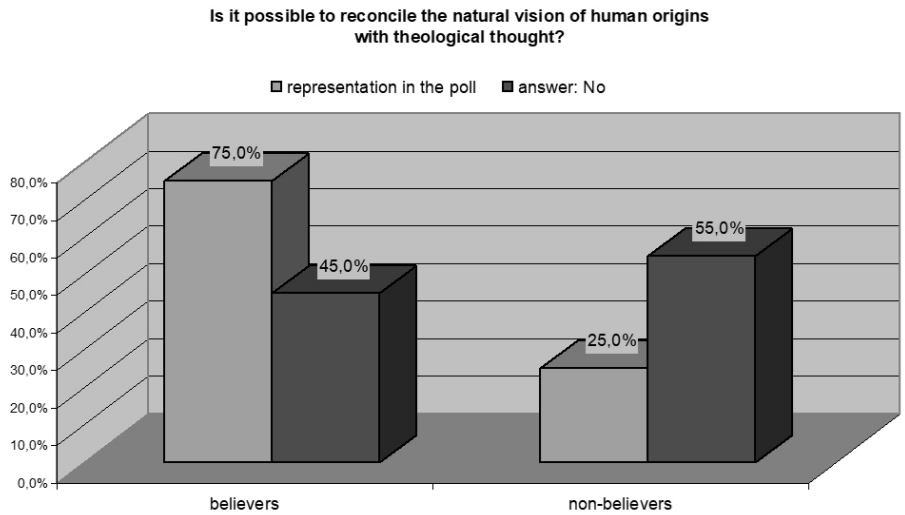

Fig. 4: No' answer with regard to the attitude towards religious beliefs

As shown in Figure 3, 40\% of the negative answers to the question of reconciliation were given by scientists, which is in nearly perfect agreement with the overall representation of this category of respondents in the poll (39.3\%). Clearly, scientists do not show any special inclination toward denying the possibility that scientific and religious views on human origins can be integrated into a coherent unity. On the other hand, the 'overrepresentation' of non-believers in the total number of negative answer is impressive: $55 \%$ of the negative answers were given by non-believers, who constitute only $25 \%$ of the overall poll participants.

Interestingly, the conclusion that the position one takes in evolution-creation controversy is not influenced by one's knowledge and expertise, but by subjective factors and personal beliefs should not be surprising - the majority of the poll participants are aware of that. This shows in their answers to another question, where nearly $60 \%$ of the respondents acknowledged that one's preference toward the idea of evolution or creation is decided not by academic views but by one's outlook on life (see Figure 5). 
Is it the case, that affirmation of the idea of evolution or creation is decided not by academic views but by personal outlook-on-life?

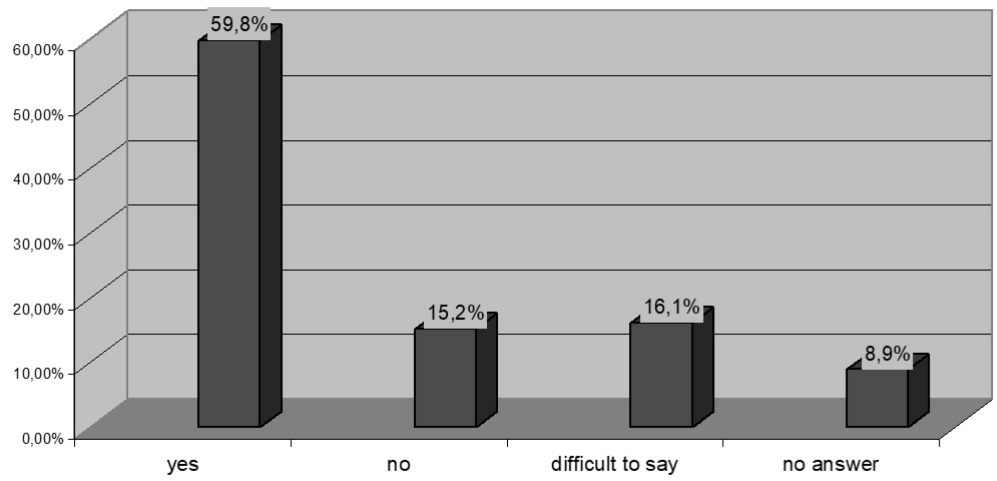

Fig. 5: Subjective reasons for deciding between evolution and creation

All this shows that the association between scientific background and the denial of the possibility of finding ways to reconcile science and religion is nothing but unfounded superstition. The evolutioncreation controversy takes place, at least for the most part, not on objective grounds of critical knowledge, but in the subjective realm of our irrational convictions.

\subsection{REASONS FOR DENYING THE POSSIBILITY OF RECONCILIATION}

Most of the questions in the questionnaire were open. Respondents were asked not only to thick one (or more) of the answers provided, but were also encouraged to comment or justify their answers to closed questions. Most of them were kind enough to do so, and many of them provided researchers even with short essays on various aspects of the evolution-creation controversy. Although these comments cannot be analyzed statistically, they are an important source for essential analysis. Such analysis reveals six groups of reasons for denying the possibility of reconciling scientific and theological accounts of human origins. 
ASSUMPTIONS

For some of the respondents, the evolution-creation controversy appears to be decided already at the level of (implicit) assumptions. One account offers a form of exclusive alternative: either the biblical story of creation is true, or truth lies in evolutionary explanations. If one accepts the theory of evolution (more precisely: one of the possible theories of that process ${ }^{18}$ ), then one has to reject the idea of creation, and vice versa: "The human is a result of evolution and not of an act of creation"; "One cannot exclude the human from evolutionary processes". Such opinions are apparently held by those who, given the alternative, vote for evolution. They implicitly deny, therefore, that we can have both. They imply also, that everybody who accepts the truth of creation would have to reject evolution, at least with regard to humans. The same exclusive alternative is assumed by those who are inclined to favour creation: "Reconciliation of creation and evolution is impossible, because God created humans"; "Is the origin of humans a natural process, or does it still require a supernatural intervention?". According to such opinions, if one believes in creation, then one has to maintain that no natural phenomena could lead to the origin of man. Accepting such an alternative 'resolves' the evolution-creation controversy at the very beginning and does not allow for any further considerations concerning, for example, various possible interpretations of the act of creation.

A different assumption is that if we wanted to look for a coherent, 'scientific-biblical' account of the origin of man, we would have to find it within evolutionary biology. "Evolutionism does not take into account supernatural powers"; "Science acknowledges only natural causes". Such quotes reveal that their authors are not aware of, or do not accept other, perhaps more subtle options, including the possibility

18 In this paper, the theory of evolution is meant to characterize some kind of evolutionary explanation. 
to build a philosophical account of human evolution, based on both scientific explanations and theological narratives. A similarly narrow perspective is employed by those who oppose the reconciliation from a religious perspective: "Natural sciences understand human reality in an exclusively materialistic way"; "Natural vision rejects reasoning pointing toward the First Thought, that is - God". Although they rightly point to the naturalistic methodology of science, those who hold such a view implicitly assume that in resolving the evolutioncreation controversy, one would have to rely solely on science and thus impose on biology a kind of reasoning that is alien to this discipline. It is worth noticing that the controversy is 'solved' at the level of assumptions here as well - this time it is a 'tertium non datur' position: no 'third party', like philosophy, is allowed to serve as a middle ground for ideas coming from scientific and theological traditions.

\section{DEFINITIONS}

Another reason for rejecting the idea of creation in the light of evolution, or denying evolution on the grounds of the belief in creation, stems from specific definitions of 'evolutionism' and 'creationism. ${ }^{19}$ For some, evolutionism is a materialistic ideology and as such is intrinsically hostile to religion. Such an understanding of evolutionism is, however, highly misleading. It is partly a heritage of the early reception of Darwin's work and attempts to use his ideas as a weapon against religion. In the context of our research, it may be also due to recent Polish history, when 'materialistic' usually meant 'anti-religious'. For these reasons, some biologists do not accept the very term 'evolutionism' as it does not describe properly their evolutionary

19 The notion of 'creationism' appears to have a defined meaning, pointing to specific views that are more socio-political and religious than rational. In this paper however, 'creationism' refers to the theological truth of creation, which has little in common with such propositions as creation science and the like. 
ideas. All -isms tend to have ideological connotation, which is lacking in the theory of evolution properly understood.

A fundamental discordance between evolutionism and creationism is also seen in their alleged metaphysical engagement. Some hold that these views are based on contrary metaphysical assumptions: materialism and spiritualism, respectively. While it is true that scientific theories are informed by philosophy, it would be unjustified to maintain that the theory of evolution inevitably implies materialistic monism. Evolutionism is certainly materialistictogether with all scientific ideas. They are so because of a justified scientific methodology which requires explanations of empirical phenomena that must not refer to any supernatural powers and beings. Methodological naturalism in science does not imply, however, any ontological decisions as to what may and may not exist. Therefore, the theory of evolution is materialistic not in terms of a metaphysical stance, but rather as a methodologically restricted achievement of science.

Applying specific definitions of evolutionism and creationism again 'resolves' the controversy at its roots: there is no place for further consideration of the details of these viewpoints and a conclusion follows instantly, namely inevitable controversy. Such definitions, however, do not do justice to either of the positions involved in the debate.

\section{SEMANTIC VIEWPOINTS}

According to one of our respondents, when comparing 'the natural vision of human origins with theological thought' we should not see the problem in terms of a conflict or concordance. What we have here, instead, is a 'semantic confrontation' between sentences that are meaningful and sentences deprived of sensible meaning. Strictly speaking there is no such thing as 'theological thought', because 'thought' - in this context - is a sentence which has meaning. Since 
theology is neither empirical nor analytical, it does not contain meaningful sentences.

One would think that positivistic criteria of meaningfulness were shown to be too narrow and inaccurate long ago. Let us just note that those who hold them valid have to 'resolve' the evolution-creation controversy not by going into relevant details, but by a preliminary semantic choice. In fact, according to this position the very comparison between creationism and evolutionism would be meaningless - they can be neither coherent nor in conflict, because there is nothing that can be compared.

\section{EPISTEMOLOGICAL POSITIONS}

Constructing a coherent view of human evolution, which would draw from both science and theology becomes by definition an impossible task, if the sources of all valuable knowledge are restricted to scientific cognition. If, for any reason, someone affirms that theology can offer nothing but stories and myths, then the answer to our question whether theology and science can be integrated into a coherent unity has to be negative. It is fairly obvious that a necessary condition of any attempt to somehow bring together theological and scientific accounts of human evolution is to accept that, although science and theology build their theories on different sources, both can offer a worldview. Whether those worldviews can be coherent or are mutually exclusive is a further question which requires careful analysis. In order to allow for such analysis, however, it is necessary to accept in the first place that theology can contribute to our knowledge. Otherwise, our problem is again only seemingly resolved, this time by epistemological choices.

Some of the poll participants go in the opposite direction, and perceive evolutionism and creationism as theories of the same epistemic type. What follows from such a position, however, is also a negative answer to the question of reconciliation. If both theories are 
seen as aiming at describing and explaining the same facts, and both are to be judged by the same standards, then they have to compete. When we compare them, we have to decide which of them serve such a descriptive and explanatory purpose better. In turn, if the standards are to be scientific, then creationism, being a theological theory, loses to its competitor by assumption. Creationism, however, understood as a religious and theological idea (as different, therefore, from 'creation science', the Intelligent Design theory, and the like) does not belong to the same epistemic type as evolutionism.

Those who could perhaps agree that theology can yield valuable knowledge, despite not being epistemically equivalent to natural sciences, would not necessarily open up the possibility of searching for a coherent view of human evolution. Another obstacle in this regard is the demand of epistemological purity. "From scientific premises can only follow scientific conclusions". Similarly, the same applies to theological premises and conclusions. As a result, the two realms of knowledge can never meet. What is at stake here is the well-known thesis of the independence (or separation) of science and religion. This thesis is justified, but it doesn't have to be the last word in the search for a possible coherence of evolution and creation. Science and theology should rightly enjoy their independence premises taken from one of them cannot decide internal aspects of the other. However, this does not have to apply to external attempts at comparing and, maybe, reconciliating the views and ideas coming - independently - from both.

PRAGMATIC REASONS

The last group of reasons for rejecting the possibility of reconciling evolution and creation, which do not touch the subject-matter of the controversy, but decide the issue on other types of considerations, may be called pragmatic. Theological and evolutionary accounts of human being usually yield different conclusions, as shown for instance 
in the case of human morality. Science and religion offer different interpretations of the motives and goals of human acts. Whether or not their interpretations have to be mutually exclusive, it is clear that the discussion would not concern the question of the origin of man as such, but the possible implications of a previous answer to that question. In other words, when evolutionism and creationism are used as interpretative tools a controversy arises because the resulting explanation of what is interpreted is different.

A negative answer to the question of reconciliation was also given by those who reject the very existence of the Creator (though not by all of them). For some of our respondents, such a rejection is just another way of declaring themselves as non-believers and does not require further justification. For others, their disbelief is motivated by personal experience or general reflection on, for example, the evil existing in the world. Regardless of the motivation (if expressed), given that a Creator does not exist, the idea of creation is consequently meaningless. Hence there is nothing to be compared and reconciled with the evolutionary account of human evolution. As we can see, here a negative answer follows necessarily on the grounds of personal convictions - the idea of creation is not seen as a theoretical possibility, but rather as a matter of beliefs. Such a perspective implies that one's opinion on the whole evolution-creation controversy is decided by personal choice, and not by considering the details of the relevant viewpoints.

REASONS OF THE CONTROVERSY

By the reasons of the controversy we mean to characterize those aspects of the evolution-creation controversy which directly refer to the content of the allegedly competing accounts of human origins. Since the aim of this section is merely to classify the arguments for the negative answer to the question of the reconciliation of evolution and creation, we highlight such reasons without discussing them. 
Evolutionary processes that lead to the origins of species, including Homo sapiens, are governed by chance. This is true with regard to genetic mutability (the bedrock of natural selection) as well as to specific mechanisms of speciation (for example, geographic isolation). What exactly does the notion of 'chance' mean in these contexts? Is it in an unavoidable opposition to the belief in a Creator who intends and wants his creatures? Does the random character of evolutionary processes exclude a First Cause of all beings? In what sense is nature 'blind' and aimless? Is it possible to reconcile the natural aimlessness with such ideas as, for example creatio continua? These are but a few questions that need careful consideration.

A fairly common way of 'defending' religious belief in creation is by applying the Cartesian body-soul dualism. The view that the human body is a product of natural processes, whereas the human soul is created by God, was one of the first theological answers to the Darwinian challenge and it is still accepted by many. However, this dualistic approach appears difficult to defend, at least when speaking of such features as abstract thinking, ${ }^{20}$ traditionally attributed to our soul. The search for a reconciliation of creation and evolution should therefore draw on other accounts of the human person available in Christian theology, which has quite a rich tradition of non-dualistic anthropology.

It is now widely accepted that an important task for science-andreligion dialogue is the reinterpretation of some of the Christian dogmas. ${ }^{21}$ In the history of the evolution-creation dispute, a particularly controversial issue has been the truth of the original

20 Cf. G. Bugajak, J. Tomczyk, Human Origins: Continuous Evolution versus Punctual Creation, in: P. Das (ed.), Global Perspectives on Science and Spirituality, Templeton Press 2009, 143-164.

21 E.g. M.W.S. Parsons, Scientific and Theological Discourse: From Dialogue to Integration, in: N.H. Gregersen, U. Görman, C. Wasserman (eds.), Studies in Science and Theology, vol. 6: The Interplay Between Scientific and Theological Worldviews (part II), Labor et Fides, Geneva 1998, 131-140. 
sin. Theological teaching seemed to require monogenism to explain this "flaw in human nature" to which everybody is subject. The notion of monogenism, however, is alien to evolutionary accounts of the development of the living world. Some theologians addressed this problem $^{22}$, but it is still an open question how the mystery of the original sin should be explained in evolutionary terms.

\section{CONCLUSIONS}

The results presented in this paper show that the position one takes in the evolution-creation controversy is related more to religious (dis) beliefs than to one's professional expertise. It has also been shown that the controversy has many facets and that the denial of the possibility of reconciling scientific knowledge with theological truths about human evolution may have various reasons. Some of them lie in the personal convictions of those who maintain that one can either value the achievements of science in explaining our evolutionary origins or believe in creation. Other reasons do not engage essential aspects of the problem, but follow from preliminary assumptions and definitions, or semantic and epistemological positions. While the latter are important and at least some of them can be defended, applying them leads to 'resolutions' of the problem which in fact make a real discussion impossible. Instead, what may and needs to be discussed by those who hope to reconcile evolution and creation are foundational issues such as the problem of chance versus divine Providence, body-soul dualism, original sin and monogenism, which indeed seem to present a substantial challenge for scientifically informed theologians and believers.

22 E.g. K. Rahner, Theologisches zum Monogenismus, in: K. Rahner (ed.), Schriften zur Theologie, vol. 1, Johannes Verlag, Einsiedeln 1954, 253-322; K. Rahner, Die Hominisation als theologische Frage, in: K. Rahner, P. Overhage (eds.), Das Problem der Homonisation, Herder, Freiburg 1961, 13-90; K. Rahner, Erbsünde und Evolution, Concilium (1967)3, 459-465. 


\section{BIBLIOGRAPHY}

"De charactere historico trium priorum capitum Geneseos. Sul carattere storico dei tre primi capitoli della Genesi", Acta Apostolicae Sedis, vol. 1, Libreria Editrice Vaticana 1909, 567-569.

Barret P., Science and theology since Copernicus. The search for understanding, Bloomsbury - T. and T. Clark London - New York 2004.

Bartmann B., Lehrbuch der Dogmatik, vol. 1, Herder, Freiburg 1911.

Bugajak G., Tomczyk J., Human Origins: Continuous Evolution versus Punctual Creation, in: P. Das (ed.), Global Perspectives on Science and Spirituality, Templeton Press 2009, 143-164.

Dawkins R., The God Delusion, Houghton Mifflin, Boston 2006.

Ecklund E.H., Scheitle C.P., Religion among Academic Scientists: Distinctions, Disciplines and Demographics, Social Problems 54(2007)2, 289-307.

Haeckel E., Ueber unsere gegenwärtige Kenntnis vom Ursprung des Menschen, Verlang von E. Strauss, Bonn 1899.

Janssens L., (ed.), Summa Theologica ad modum commentarii in Aquinatis summam praesentis aevi studiis aptatam, vol. 1, Herder, Freiburg 1912.

Kloskowski K., Filozofia ewolucji i flozofia stwarzania, vol. 1: Między ewolucja a stwarzaniem, Wydawnictwo ATK, Warszawa 1999.

McGrath A.E., McGrath J.C., The Dawkins delusion. Atheist fundamentalism and the denial of the divine, InterVarsity Press, Downers Grove 2007.

Moore J., The Post-Darwinian Controversies, Cambridge 1979.

Parsons M., Scientific and Theological Discourse: From Dialogue to Integration, in: N.H. Gregersen, U. Görman, C. Wasserman (eds.), Studies in Science and Theology, vol. 6: The Interplay Between Scientific and Theological Worldviews (part II), Labor et Fides, Geneva 1998, 131-140.

Pohle J., Lehrbuch der Dogmatik, vol. 1, Schöningh, Padeborn 1908.

Rahner K., Die Hominisation als theologische Frage, in: K. Rahner, P. Overhage (eds.), Das Problem der Homonisation, Herder, Frieburg 1961, 13-90.

Rahner K., Erbsünde und Evolution, Concilium (1967)3, 459-465.

Rahner K., Theologisches zum Monogenismus, in: K. Rahner (ed.), Schriften zur Theologie, vol. 1, Johannes Verlag, Einsiedeln 1954, 253-322.

Russell C.A., Cross-currents: interactions between Science and Faith, London 1985. Schönborn C., "Finding Design in Nature", New York Times, 2005, July 7.

Schönborn C., Chance or purpose? Creation, evolution, and a rational faith, ed. H.P. Weber, transl. H. Taylor, Ignatius Press, San Francisco 2007. 
Tomczyk J., Bugajak G., Kontrowersje wokót powstania cztowieka - wstępna analiza ankiet studentów, Studia Ecologiae et Bioethicae 5(2007), 43-59.

Tomczyk J., Bugajak G., On Evolution and Creation. Problem solved? - The Polish example, Zygon - Journal of Religion and Science 44(2009), 859-878.

Tomczyk J., Bugajak G., Wokót erwolucji i kreacji - wstępna analiza ankiet nauczycieli istudentów, Studia Ecologiae et Bioethicae 4(2006), 181-199.

\section{Grzegorz Bugajak}

Uniwersytet Kardynała Stefana Wyszyńskiego w Warszawie, Instytut Filozofii (Cardinal Stefan Wyszyński University in Warsaw, Institute of Philosophy, Poland)

ORCID: https://orcid.org/0000-0003-0536-1254

Jacek Tomczyk

Uniwersytet Kardynała Stefana Wyszyńskiego w Warszawie, Instytut Nauk Biologicznych

(Cardinal Stefan Wyszyński University in Warsaw, Institute of Biological Sciences, Poland)

ORCID: https://orcid.org/0000-0002-0605-665X

j.tomczyk@uksw.edu.pl

DOI: $10.21697 /$ spch.2020.56.4.02 